\title{
Strengthening Students' Independent Character Through a Systematic Online Learning Model at SD Negeri Sidanegara 04 Cilacap
}

\author{
Pratikno $^{1}$, Wakhudin ${ }^{2}$ \\ \{ pratiknopastibisa@gmail.com ${ }^{1}$, wakhudin@ump.ac.id ${ }^{2}$ \} \\ ${ }^{1}$ SD Negeri Sidanegara 04, Cilacap \\ ${ }^{2}$ Magister Pendidikan Dasar, Universitas Muhammadiyah Purwokerto
}

\begin{abstract}
Character education is one of the efforts to achieve national education goals. Efforts to establish character values through habituation starting from home, community and at school. The purpose of this study was to determine the planning of learning with a systematic online learning model at SD Negeri Sidanegara 04. The method used in this study was an experimental method using a quasi-experimental design in the form of a nonequivalent control group design. The population was grade fifth second semester SD Negeri Sidanegara 04 in the academic year 2020/2021. The sampling technique in this study was saturated or census samples. Data collection techniques are using tests and documentation. The test method is through an independent character questionnaire that uses a Likert scale to measure students' independent character. This study used the t-test analysis method with the help of SPSS 25 . From the results of the data analysis, the posttest means score of the experimental class was 97.44, and the posttest average score for the control class was 86.05. The statistical analysis results using the t-test through SPSS 25 obtained Sig (2-tailed) 0.000 with a significance level of $\alpha=0.05$. The conclusion of the study states that there is a difference in learning using systematic online learning methods towards strengthening independent character in fifth grade students at SD Negeri Sidanegara 04 in the academic year 2020/2021.
\end{abstract}

Keywords: independent character, systematic online learning model

\section{Introduction}

The Government of the Republic Indonesia issued regulation Number 21 of 2020 concerning large-scale social restrictions (PSBB) in the context of accelerating the handling of Corona Virus Disease 2019 (Covid-19). 19) in such a way as to prevent the possible spread of Corona Virus Disease 2019 (Covid-19). The Minister of Education and Culture of the Republic of Indonesia issued circular letter number 4 of 2020 regarding the implementation of education policies in the emergency period of the spread of Covid-19 that the learning process is carried out from home.

Human resources are critical capitals in advancing a country apart from natural resources, infrastructure, and technological development [1]. Education includes all aspects, both education within the family, community, and at school. Best is by the objectives of national education as stipulated in Law Number 20 of 2003, which states that national education aims to develop the potential of students to become human beings who believe and fear God Almighty, have a noble character, are healthy, knowledgeable, competent, creative, independent, and become democratic and responsible citizens [2]. The conclution from of national education, character education is needed to form quality human resources. 
Character education is activities carried out with all the power and efforts consciously and planned to direct students [3]. Character education is also an activity process that improves the quality of education and the development of a character of harmony that always teaches, guides, and fosters every human being to have intellectual competence, character, and exciting skills. The values of character education that kind of are religious, nationalist, intelligent, responsible, disciplined, independent, honest, wise, respectful, polite, generous, helpful, mutual, confident, hard work, challenging, creative, leadership, democratic, humble, tolerant, solidarity and caring. Efforts to form character values are through habituation both in the home, community, and school environment. The learning process carried out in the school environment includes the cognitive, affective, and psychomotor domains. Based on Presidential Regulation number 87 of 2017 concerning strengthening character education that extracurricular character education is integrated with teaching and learning activities [4].

The impact of the Circular of the Minister of Education and Culture Number 4 of 2020 resulted in learning that usually occurs face-to-face in the classroom switching to distance learning [5]. One of the information technologies that play a role in education is online learning [6]. Several applications can help online learning activities, for example, WhatsApp, zoom, web blog, Edmodo, and others [7]. Implementation distance learning that is required online because where schools cannot bring students to school [8]. The government give internet credit for teachers, and students to facilitated online learning. So that educators must be able to master the online learning application mode. However, the facts in the field are that educators and students are still adapting to online learning. Likewise, what happened at SD Negeri Sidanegara 04 Cilacap.

The role of parents in learning assistance for students results in students becoming not independent. Many parents of SD Negeri Sidanegara 04 students complain that their sons and daughters rely heavily on their parents in doing the tasks assigned by educators online. Even though students should be independent in learning, to overcome the negative impact of online learning, educators must try to innovate existing learning models to strengthen the independent character of students. Independent character is needed because the development of global society and various information requires community, individuals, and students to choose the correct positive details [9].

\section{Research Methods}

This research is using the experimental method. An experimental research method can interpreted as a research method used to find the effect of specific treatments on others under controlled conditions [10]. Quantitative research is typically associated with the process of enumerative induction, that is, drawing conclusions based on numbers and making abstracts based on generalizations. Implementation this study by manipulating treatment to test the variable to be studied ( dependent variable ). The experimental method is validation or testing, which tests the effect of one or more variables on other variables. Variables that impact are grouped as independent variables, and variables that are affected are grouped as dependent variables [11]. A research method has a specific research design. This design describes the procedures or steps that research, the research time, the source of the data and the conditions in which the data obtained, and how the information is collected and processed [11] The method used in this research is an experimental method with a quasi-experimental design. This form of experimental design is a development of true-experimental design, which is challenging to implement. This design has a control group, but it cannot fully function to control external variables that affect the implementation of the experiment [10]. Researchers used a quasiexperimental design nonequivalent control group design. According to Sugiyono [10], this 
design is almost the same as the pretest-posttest control group design, but in this design the experimental group and the control group were not chosen randomly.

Table 1. Quasi-Experimental Design in the form of Nonequivalent Control Group Design

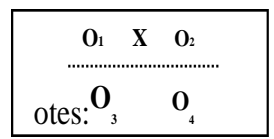

$\mathrm{O} 1=$ pretest experimental group

$\mathrm{O} 2$ = posttest experimental group

$\mathrm{O} 3=$ control group pretest

$\mathrm{O} 4$ = posttest control group

$\mathrm{X}=$ treatment, namely by using a systematic online learning model

Results of the research with comparing the pretest and posttest results from the experimental group and the control group. The treatment effect is $(\mathrm{O} 2-\mathrm{O} 1)-(\mathrm{O} 4-\mathrm{O} 3)$.

The steps for the research procedure carried out by the researcher are as follows:

a. Conducting a pretest on grade 5 students at SD Negeri Sidanegara 04;

b. Based on the results of the pretest, there is two groups in grade fifth from 37 students, namely the experimental group and the control group, with a balanced comparison according to the standard distribution curve;

c. The experimental group was given independent character reinforcement by using a systematic online learning model for a certain period;

d. Provide posttest to the experimental group and the control group;

e. Comparing the results of the pretest and posttest from the experimental group and the control group $(\mathrm{O} 2$ - O1) - (O4 - O3) to determine the effect of the independent character strengthening treatment using a systematic online learning model;

f. Apply a suitable statistical analysis to determine whether the effect of strengthening the independent character is significant or not.

\section{Research Results}

Before the research was conducted, field permits were arranged, research proposals were made, and the research plan was disseminated to the school where the research was conducted. The second preparation is instrumental, namely testing the validity and reliability of the instruments to be used.

Instrument testing was carried out before the instrument was used as a data collection tool. Before testing the instrument, it is first validated by an expert, and then testing the research instrument is carried out to students outside the population. The results of the instrument trial were then analyzed to determine the validity and reliability of the instrument.

The calculation of the validity test of the questionnaire instrument was carried out using the product-moment correlation formula. The data obtained were then tested for validity which help using SPSS 25. The instrument's validity was measured based on the validity criteria, which stated that if r-count $\geq$ r-table, then the instrument was declared valid, but if $r$-count $<r$-table, 
then the instrument was declared invalid. When the r-table uses the significant level $\alpha=0.05$ with $\mathrm{n}=30$, so the $\mathrm{r}$ table value is 0.361 .

Calculations using SPSS 25 obtained data on the 25 question items on the independent character questionnaire instrument with r-count values in the range of $0.364-0.865$. Based on this data, there are 25 instrument items in the independent character questionnaire declared valid. Find out the 25 questions that were declared valid can be seen in table 13 .

Table 2. Field Trial Validation Results

\begin{tabular}{|c|c|c|c|c|c|}
\hline & & Valid & & Invalid & \\
\hline Number & Indicator & Question Items & Amount & Question Item & Amount \\
\hline 1 & $\begin{array}{l}\text { Doing homework without copying the work of a } \\
\text { friend }\end{array}$ & $1,2,3,4$ & 4 & & - \\
\hline 2 & $\begin{array}{l}\text { Finding resources to complete schoolwork without } \\
\text { the help of the school librarian }\end{array}$ & $5,6,7$ & 3 & & - \\
\hline 3 & $\begin{array}{l}\text { A condition in which a person has a competing } \\
\text { desire to advance for his good }\end{array}$ & $\begin{array}{l}8,9,10,11,12 \\
13,14\end{array}$ & 7 & & - \\
\hline 4 & $\begin{array}{l}\text { Able to take decisions and initiatives to solve the } \\
\text { problems at hand }\end{array}$ & $\begin{array}{l}15,16,17,18,1 \\
9\end{array}$ & 5 & & - \\
\hline 5 & Have self-confidence and carry out their duties & $20,21,22$ & 3 & & - \\
\hline 6 & $\begin{array}{l}\text { Take responsibility for what is done. } \\
\text { AMOUNT }\end{array}$ & $23,24,25$ & $\begin{array}{l}3 \\
25\end{array}$ & & - \\
\hline
\end{tabular}

The reliability test of the independent character questionnaire from on 25 item questions declared valid. The reliability test is calculated using the Spearman-Brown formula. After calculating using SPSS 25, the value is 0.846. Based on this data, the 25 items of the independent character questionnaire were declared reliable.

Research data obtained from the test before being given treatment (pretest) and data from the test results after treatment (posttest). The test questions are in the form of a questionnaire about independent characters consisting of 25 questions in the format of google form. Results of the research in the form of pretest and posttest values were explained in the data description for got the complete data.

Table 3. Descriptive Statistics Data

\begin{tabular}{|c|c|c|c|c|c|}
\hline & & Pretest_Eksperimen & $\begin{array}{c}\text { Posttest_Eksperi } \\
\text { men }\end{array}$ & Pretest Kontrol & Posttest_Kontrol \\
\hline \multirow[t]{2}{*}{$\mathrm{N}$} & Valid & 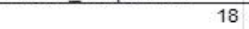 & 18 & 19 & 19 \\
\hline & Missing & 1 & 1 & 0 & 0 \\
\hline \multicolumn{2}{|c|}{ Mean } & 78,94 & 97,44 & 78,11 & 86,05 \\
\hline \multicolumn{2}{|c|}{ Std. Error of M ean } & 1,683 & 1,039 & 1,424 & 1,601 \\
\hline \multicolumn{2}{|c|}{ Median } & 79,50 & 97,00 & 77,00 & 85,00 \\
\hline \multicolumn{2}{|c|}{ Mode } & $79^{2}$ & 93 & 77 & $75^{2}$ \\
\hline \multicolumn{2}{|c|}{ Std Deviation } & 7,141 & 4,409 & 6,208 & 6,980 \\
\hline \multicolumn{2}{|c|}{ Variance } & 50,997 & 19,438 & 38,544 & 48,719 \\
\hline \multicolumn{2}{|c|}{ Range } & 28 & 15 & 22 & 23 \\
\hline \multicolumn{2}{|c|}{ Minimum } & 64 & 91 & 67 & 75 \\
\hline \multicolumn{2}{|c|}{ Maximum } & 92 & 106 & 89 & 98 \\
\hline \multicolumn{2}{|c|}{ Sum } & 1421 & 1754 & 1484 & 1635 \\
\hline
\end{tabular}

Based on the descriptive statistical data above, the average posttest result for the experimental class was 97.44 and the posttest result for the control class was 86.05. The difference in the average value indicates a difference in the conditions before and after being given treatment. 
The data has met the requirements for the t-test, which is normally distributed and homogeneous. The next stage is that the data obtained is tested differently using SPSS 25 . The results of the different tests using SPSS 25 are as follows.

Table 4.Independent t-test results using SPSS 25

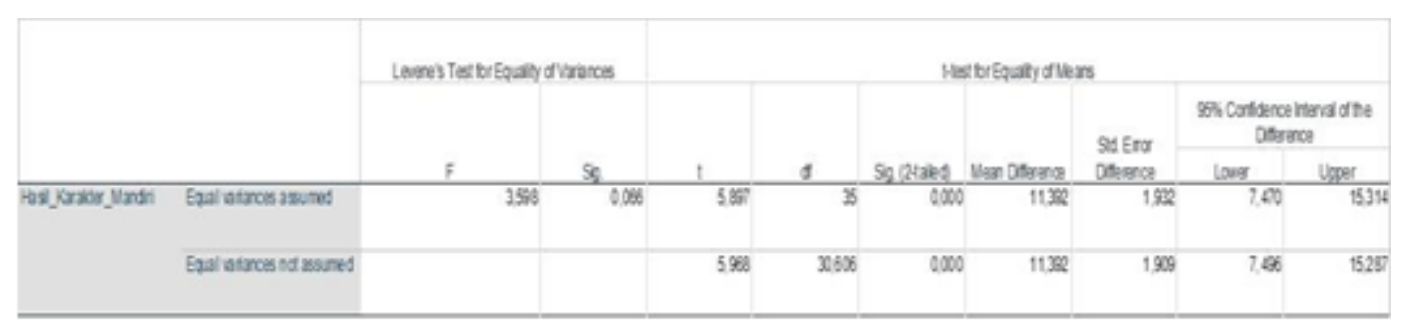

Based on the data obtained from the results of the independent t-test using SPSS 25, conclution from this study that there is a difference between before treatment and after treatment in the experimental class. Based on the results that Sig. (2-tailed) 0.000 below the significance level of 0.05 , which means that there is a significant difference between before and after treatment using a systematic online learning model.

The hypothesis which reads "There is a significant difference in strengthening independent character by using a systematic online learning model in class V semester 2 SD Negeri Sidanegara 04 Cilacap" can be accepted as true because through systematic online learning students experience increased strengthening of students' independent character. Increasing the existing independent character is one of the impacts of using a systematic online learning model, where online learning activities are well organized and planned, so that students obey the rules in online learning and carry out teaching and learning activities independently. This is because through a systematic online learning model students are able to download materials, view videos according to the existing material, do assignments on the links provided and immediately see the results of their scores. In addition, students continue to carry out learning activities that are two-way between teachers and students. Two-way learning is a learning activity that provides opportunities for students to play an active role, so that even though learning online students do not feel bored and can still interact with friends and teachers in online classes.

Reni Nurazizah from the book with title An independent character of students in learning during the pandemic [13] explain that "Independent character is education or conscious effort with the aim of shaping the morals,character or character of an individual so that his life does not continue to depend on thehelp of others in solving anything as long as he is able to solve it himself." Daniel Dike, Lusilla Parida and Ivan Stevanus says that The Covid-19 pandemic has generated a new awareness of the importance of education as a shared responsibility and has encouraged the participation and the collaboration at the level of the student's character building, related to learn how to learn. Strengthening the process and the quality of learning outcomes in the online character education transformation scheme in the elementary schools requires a character education approach which is not instructional only. The non instructional classroom-based learning approaches in the context of online learning during the Covid-19 pandemic are significant and relevant. It is important for the teachers to strengthen their inquiry-reflective capacity by utilizing non-instructional fields to support the optimal implementation of the independent learning concept from home. This can be achieved by the class management empowerment, the learning methods selection, the learning rules and procedures, the motivation development, the joint commitment and the development of the 
physical environment with the aim of the students learn independently and meaningfully from home [13].

\section{Conclusion}

Based on the results of the analysis and discussion on strengthening the independent character of students through a systematic online learning model at SD Negeri Sidanegara 04 Cilacap, it can be concluded as follows:

1. Learning planning using a systematic online learning model at SD Negeri Sidanegara 04 Cilacap is not much different from offline learning. Things that need to be prepared before the implementation of learning such as teacher administration, preparing online learning media to be used (google classroom, youtube, zoom) and equipped with materials, questions, and the value of learning outcomes.

2. The implementation of online learning using a systematic online learning model at SD Negeri Sidanegara 04 went well, students were able to participate in internet-based learning. Based on the results of peer observations, students learn actively through online learning, teachers familiarize students with online learning by utilizing online applications so that IT-based learning accelerates in elementary school students.

3. The systematic online learning model for strengthening the independent character of students at SD Negeri Sidanegara 04 Cilacap has a significant impact. It is known from data processing with calculations using SPSS 25, the probability value or Sig (2 tailed) is obtained.0.000. The probability value or Sig ( 2 tailed) is $0.000<0.05$, which means Ho is rejected and $\mathrm{Ha}$ is accepted. The conclusion of the research obtained is that Ha is accepted which reads "There is a significant difference in strengthening independent character by using a systematic online learning model for fifth semester students of SD Negeri Sidanegara 04 Cilacap".

\section{References}

[1] Harahap S. Islam dinamis: menegakkan nilai-nilai ajaran al-Qur'an dalam kehidupan modern di Indonesia. PT. Tiara Wacana Yogya; 1997..

[2] Departemen Pendidikan Nasional. Undang-Undang Nomor 20 Tahun 2003 Tentang Sistem Pendidikan Nasional. Jakarta: Depdiknas. 2003.

[3] Khan Y. Pendidikan karakter berbasis potensi diri. Yogyakarta: Pelangi Publishing. 2010.

[4] Departemen Pendidikan Nasional. Peraturan Presiden Republik Indonesia No. 87 Tahun 2017 tentang Penguatan Pendidikan Karakter. Jakarta: Depdiknas. 2017.

[5] Kemdikbud. Surat Edaran Nomor 15 Tahun 2020 Tentang Pedoman Penyelenggaraan Belajar Dari Rumah Dalam Masa Darurat Penyebaran Corona Virus Disease (COVID-19). Jakarta: Kementerian Pendidikan dan Kebudayaan. 2020.

[6] Sofyana L, Rozaq A. Pembelajaran Daring Kombinasi Berbasis Whatsapp Pada Kelas Karyawan Prodi Teknik Informatika Universitas Pgri Madiun. Jurnal Nasional Pendidikan Teknik Informatika: JANAPATI. 2019 Mar 10;8(1):81-86.

[7] Handarini OI, Wulandari SS. Pembelajaran daring sebagai upaya study from home (SFH) selama pandemi covid 19. Jurnal Pendidikan Administrasi Perkantoran (JPAP). 2020 Jul $17 ; 8(3): 496-503$.

[8] Kemdikbud. Surat Edaran Nomor 4 Tahun 2020 Tentang Pelaksanaan Kebijakan Dalam Masa Darurat Penyebaran Corona Virus Disease (COVID-19). Jakarta: Kementerian Pendidikan dan Kebudayaan. 2020. 
[9] Lindasari E. PENDIDIKAN KARAKTER MANDIRI MELALUI PEMBELAJARAN PKn DAN BUDAYA SEKOLAH (STUDI KASUS) DI SMK NEGERI 2 BANJARMASIN. Jurnal Socius. 2019;8(2): 127-139.

[10] Sugiyono. Metode Penelitian Pendidikan: Pendekatan Kuantitatif, Kualitatif, dan R\&D. Bandung: Alfabeta. 2015.

[11] Sukmadinata, Nana Syaodih. Metode Penelitian Pendidikan. Bandung: PT Remaja Rosdakarya. 2012.

[12] Nurazizah R. An independent character of students in learning during the pandemic. ETUDE: Journal of Educational Research. 2021 Jan 26;1(2):51-60.

[13] Dike D, Parida L, Stevanus I. Micro strategy and character educational transformation in elementary school during the covid-19 pandemic of sintang distric, west kalimantan province. European Journal of Molecular \& Clinical Medicine. 2020 Nov 28;7(8):775-86. 